\title{
International Factors and the 1964 Election.
}

\section{John W. Young.}

At first sight international issues had little impact on the 1964 election. ${ }^{1}$ The victor, Harold Wilson, made only limited references to foreign policy and defence during the campaign and, in a list of eleven major issues drawn up by National Opinion Polls (NOP), defence and foreign affairs came at the end with barely one in ten voters deeming them significant - well behind the cost of living (79\%), education (29\%) and housing (27\%). The only noteworthy defence issue in voters' minds was Britain's nuclear deterrent, important enough to be treated as a distinct measure in the NOP poll, but even that scored a lowly 13\%. Traditionally, of course, foreign and defence policy have had only a limited impact on British general elections, surprisingly perhaps given the size of the country's Empire, the economy's dependence on international trade and the proportion of national wealth dedicated to defence. The 'Khaki election' of 1900 during the Boer War, the 1918 election with its talk of 'hanging the Kaiser', and the 1935 election in which issues surrounding 'collective security' loomed large, were exceptions to the rule. Even humiliation during the Suez Crisis in 1956 had not prevented the Conservatives being re-elected with a healthy majority three years later.

Then again, the 1964 election was one of the most closely run in British history and an analysis of the campaign shows that, interpreted broadly, international questions did have a real effect on the contest. The sitting Prime Minister, Alec Douglas-Home, 
focused on the future of the nuclear deterrent for much of the campaign, while considerations about the country's relative decline in the world, reflected in chronic balance of payments problems, all helped Labour's case that it was 'time for change' at the top. Even if international issues have not generally loomed large in British elections, a study of the links between the two is valuable for a number of reasons, not least because this is a little studied era. Among historians, even the most respected figure may write an account of the 1964 campaign that barely mentions foreign policy and defence; while many works on British elections by political scientists rarely give much space to the international arena. ${ }^{2}$ Yet the mid-1960s were a significant point for the country's global position. The post-war policy of 'three circles', in which Britain played a major role in Europe, maintained a global Empire and influenced US policy via the 'special relationship', was being called into question. In 1962 Dean Acheson had famously remarked that 'Britain has lost an Empire and... not yet found a role.' The value of the Commonwealth was in doubt, a bid to enter the European Community had failed, the position of the Pound as a global trading currency was fading and, after 1963, the US administration of Lyndon Johnson seemed less disposed than its predecessors to treat London as a 'special' partner.

While the historiography of Britain's international policy in the mid-1960s is still limited, enough work has been done on the increasingly difficult state of the 'special relationship'3, conflicts in Southeast Asia ${ }^{4}$, the instability of Sterling and the withdrawal from positions East of Suez ${ }^{5}$, as well as the problems of Aden and Rhodesia ${ }^{6}$, to suggest that these questions deserved public attention in 1964. The following years were to see a 
rapid withdrawal from East of Suez, a massive devaluation of the Pound and a serious decline in British influence in Washington. ${ }^{7}$ Why, then, was there no national debate about these questions at election time? Why did the sitting Prime Minister focus so narrowly on the nuclear question, with other foreign and defence issues barely featuring in the campaign? Was his focus a wise one? And why did the manifestos of the two main parties tend to suggest a consensus position on foreign policy rather than any serious differences? This article is divided into two main parts. The first reviews Britain's place in the world in 1964 and the immediate background to the election, before surveying the manifestos and the campaigns of the two major parties. The second part analyses the campaign and suggests answers to the above questions. This also reflects on whether historians of international relations are justified in paying little attention to elections.

\section{PART 1: THE 1964 ELECTION}

\section{Britain and the World in 1964}

When Labour was last in power, under Clement Attlee in 1945-51, Britain took a lead in resisting Soviet expansion, became a founder-member of NATO and began to develop atomic weapons. While giving independence to India, the government maintained its position in the Middle East and took only a limited interest in European integration. Since then successive Conservative premiers - Winston Churchill, Anthony Eden, Harold Macmillan and Douglas-Home - had taken more interest in international than domestic 
subjects. The process of 'decolonisation' had quickened but Britain still held military bases across the Indian Ocean, from Aden to Singapore. Backed by the presence of armed forces, these were costly in terms of foreign exchange and added to balance of payments problems. So did the desire to play a central role in the world economy as banker of the Sterling Area, which still included most Commonwealth countries. Yet repeated attempts at spending restraint failed properly to link external commitments to limited resources and the Conservatives persisted in developing such costly technological projects as the TSR-2 aircraft. ${ }^{8}$ As economic uncertainty mounted, Macmillan made an application to enter the European Economic Community (EEC) in 1961, only to be vetoed two years later by Charles de Gaulle. This made the government more reliant on the Americans, a reliance emphasised by Macmillan's agreement to join a 'Multilateral Force' (MLF), through which NATO members would share the control of nuclear forces. It was a scheme for which the Conservatives actually had little enthusiasm because it was partly designed, by some advisers of US President John F. Kennedy, to undermine the independence of the British deterrent and thereby pave the way for progress on nonproliferation talks with the Soviet Union.

There were some successes however. In particular, Macmillan was able to keep the country among the nuclear powers by arranging the purchase of Polaris missiles from Kennedy, at their Nassau summit in 1962, when the President went against the views of some of his closest advisers. Also British attempts to reduce the intensity of the Cold War bore fruit in the 1963 Test Ban Treaty, which also helped reassure the public that the nuclear arms race might yet be controlled. Furthermore, Britain's predicament could not 
all be blamed on the government. The general population seem to have shared the desire to play a great power role and showed little resistance, for example, to the decision to deploy troops in Malaysia when it was threatened by Indonesia in the so-called 'confrontation' of 1963-66. ${ }^{9}$ Certainly there would be no rush by Labour to abandon Malaysia after 1964, any more than there was to break with the Americans or quickly to withdraw from bases 'east of Suez.' Even on nuclear weapons, where Labour came closest to promising a reversal of policy, there was always ambiguous noise about what a Wilson government would do. In February 1964, when pressed on the question in the Commons, the defence spokesman, Denis Healey, refused to say whether Labour would scrap Polaris. ${ }^{10}$

In mid-1964 it actually seemed that international questions might dominate the political debate: violence in Aden Colony claimed British lives, a minor scandal erupted in the defence industry (the Ferranti Affair), there was a threat of violence between the Greek and Turkish populations in Cyprus, only recently granted independence by Britain, and there was a growing danger of American involvement in the struggle between the South Vietnamese government and its Communist-led opponents. Wilson, elected to the Labour leadership in February 1963 from the position of Shadow Foreign Secretary, was keen to prove he had international stature through visits to President Kennedy and the USSR's Nikita Khrushchev. But Douglas-Home, Conservative Prime Minister since October 1963, was a former Commonwealth Secretary and Foreign Secretary, far more at home on international questions than domestic ones, who scored some successes on the foreign front in June-July. Most significantly he highlighted the potential cost to Britain 
of a 'socialist' foreign policy, when Spain cancelled a contract to build frigates under British license. This followed Wilson's criticism of the deal, leading the Spanish government (then under the dictatorship of General Francisco Franco) to fear he would not honour it. There was genuine rage in the Cabinet and determination to exploit the incident. 'When everyone else is striving to increase exports, he is striving to discourage them', remarked Douglas-Home. The Prime Minister was also keen to exploit the nuclear issue against Labour, not only because polls suggested that voters wished to retain the deterrent, but also because he had a strong personal belief in the effectiveness of nuclear defence. ${ }^{11}$ Not to be outdone, Wilson again visited Washington and Moscow and in speeches at this time, as well as in his book The Relevance of British Socialism, he advocated East-West agreements, criticised the attempt to enter the EEC and emphasised the value of Commonwealth co-operation. Neither could he be portrayed as lacking patriotism: not only did he defend the British presence in Aden and Malaysia, he also offset his talk of nuclear disarmament with a commitment to spending on conventional arms and devoted a chapter of The Relevance of British Socialism to Britain's place in the world economy. ${ }^{12}$ Despite the dangers, he also remained defiant on the Spanish frigates issue, continuing to try to tar Douglas-Home as an ally of Franco. ${ }^{13}$

Foreign and defence policies had an important role, then, in the months of sparring that preceded the election, and it may have been the Spanish frigates episode that helped put the Conservatives back in the lead in some opinion polls. There were few other issues at the time that could account for this swing in opinion back from Labour, which had seemed well ahead earlier in the year. ${ }^{14}$ Indirectly, too, questions of Britain's 
role in the world had an impact on the setting of the election. The self-doubt that was growing in Britain was closely wrapped up in a sense of declining international relevance, as the Empire was wound down, ambitions for a genuinely independent deterrent waned and de Gaulle vetoed EEC membership. While Britain appeared locked in its 'stop-go cycle' of economic inertia, the EEC economies were expanding rapidly and American political life was reinvigorated by Kennedy. Wilson, indeed, selfconsciously modelled himself on the late American President, saying in a political broadcast on 15 July that Labour wanted 'something like what President Kennedy had after years of stagnation - a programme of a hundred days of dynamic action.' It was an image the Conservatives castigated during the election with the party's vice-chair, Paul Bryan, remarking 'Wilson is no Kennedy and we are not Americans. ${ }^{15}$ In fact, as even his closest allies recognised, Wilson had no real intention of modelling himself on anyone. 'Kennedy never minded it being known that he had speech writers and advisers', complained Tony Benn, 'but Harold does.' But there was no doubt that British politics seemed to becoming 'Americanised'. Wilson took personal control of election plans, allowed only a few aides to draft the manifesto and expected advisers to take a low profile. ${ }^{16}$ And the image of a 'Presidential' system was confirmed when Douglas-Home played a dominant role in his party's campaign preparations.

Whatever the importance of international factors in the background of the 1964 election, however, it is evident that both main parties tried to manage events in such a way as to avoid embarrassment on such a sensitive area as national security and prestige. Just as they baulked at any dramatic steps to dampen demand in the economy at home, 
the Conservative government certainly tried to forestall progress on 'nuclear sharing' through the Multilateral Force in 1964, using the impending election as an excuse. On a visit to Washington in April the Foreign Secretary, 'Rab' Butler, warned the Americans that it would be impossible to make decisions on the Force before the poll ${ }^{17}$ In this sense, of course, electoral considerations had a debilitating effect on policy, preventing some questions from being properly dealt with. There was also a tendency for foreign governments to avoid making agreements with Britain before the election was decided. On becoming Foreign Secretary in October 1963, Butler had realised that it would be impossible to achieve much before the next election which, at its latest, had to be held in twelve months time. Instead he merely intended 'to probe' such issues as improved relations with the USSR and the possibilities of further nuclear disarmament. This was just as well since, when he visited Moscow in July 1964, he found that 'Soviet leaders were quite aware that a British election was looming and did not feel disposed to reach conclusions. ${ }^{18}$ The clearest evidence of political parties avoiding controversial positions on national security emerges from their election manifestos.

\section{The Manifestos}

In 1959-61 Labour had been deeply divided over nuclear weapons with advocates of unilateral nuclear disarmament triumphant at the 1960 party conference before the thenleader, Hugh Gaitskell, struck back the following year. That victory proved decisive but, given the bitterness of the debate, it was unsurprising that Labour's position on nuclear questions remained delicate and natural that Douglas-Home should seek to stir the ashes. 
While the Conservative leader said in December 1963 that 'we should not try to import foreign or defence issues into party politics', it was clear from his first speech as leader that he intended to expose divisions within Labour over nuclear weapons at every opportunity. ${ }^{19}$ And the Opposition were well aware of their lingering vulnerability on the question. The American Embassy in London noted that, when the Labour manifesto was launched at Wembley in mid-September there was little mention of foreign and defence issues. Embassy analysts could only presume that these were topics that it was 'impolitic to stress in party circles. ${ }^{20}$ Yet there was certainly no attempt to dodge foreign and defence policies in the Labour manifesto. Although one historian has written that it 'contained little on foreign affairs ${ }^{\text {'21 }}$ these issues actually took up one of the three main parts - 'a New Role for Britain' - into which The New Britain was divided. They could also be said to have been an integral part of the section on economic policy where discussion of a proposed National Plan, technology and price stability were closely related to the aim of improving the balance of payments, helping Britain pay its way in the world.

It was undoubtedly the delicacy of the subject, the danger of divisions reopening in Labour ranks and the likelihood Douglas-Home would exploit the subject, rather than any intention of utilising it at the forefront of his own campaign, which led Wilson personally to draft the sub-section of the manifesto on defence. ${ }^{22}$ This accused the Conservatives of wasting resources on high technology projects, especially missiles and aircraft, and vaguely promised 'value for money' on weapons procurement in future. More important, the defence section attacked the decision to buy Polaris missiles as a 
delivery system for the British deterrent with the pithy statement, calculated to please unilateralists, 'It will not be independent, it will not be British and it will not deter': instead it would make Britain dependent on America, encourage others ('including Germany') to want a nuclear arsenal and increase the danger of nuclear war. Yet, when it came to stating the alternative, the manifesto was again curiously vague. 'Re-negotiation' of the 1962 Nassau agreement on purchasing Polaris was promised, but on what basis was unclear, and meanwhile the V-bomber force (which did give Britain its own delivery system, though one that was increasingly obsolete) would remain. There was also condemnation of the MLF, yet Labour wanted a way of controlling NATO's nuclear weapons that gave 'all the partners in the Alliance... a proper share in their deployment and control.' And talk of 'strengthening... our conventional regular forces' sat uneasily beside the promise of 'value for money' given that, in terms of destructive power per Pound spent, nuclear weapons were cheaper. On defence then, the manifesto's purpose was to suggest real differences with the Conservatives and hint at ending the nuclear deterrent, without actually making firm undertakings. Conservative Central Office was undoubtedly correct that 'Labour utterances... reflect the need to satisfy their unilateral disarmers and neutralists, while at the same time trying to allay public misgivings about Labour's ability to defend Britain. ${ }^{23}$ Nor did policy become any more transparent during the campaign. Thus one brief insisted the manifesto 'is crystal clear' but merely repeated such promises as renegotiating Nassau and controlling nuclear weapons via NATO, without amplifying how these would work in practice. ${ }^{24}$ 
Beyond defence issues the manifesto focused on two areas, the 'End of Colonialism' and 'Prospects for Peace' where a common theme was of the Conservatives being a backward-looking, unimaginative party. The sub-section on Colonialism played up Labour's record on independence for India; it criticised the Conservatives for being dilatory over granting independence and willing to sacrifice the Commonwealth by applying to enter the EEC; and, in one of the most detailed sections in the whole manifesto, set out seven ways in which Commonwealth trade and co-operation might be improved, including the creation of a Commonwealth Consultative Assembly. The subsection also included mention of Commonwealth immigration, with an undertaking that Labour would 'legislate against racial discrimination' if it took power, and it promised expanded overseas aid. Yet, once again, on closer inspection, the impression of an enlightened pro-Commonwealth outlook was not all it seemed. Not only was there the statement 'Labour accepts that the number of immigrants entering the United Kingdom must be limited', but there was also a hint, in the remark that 'we shall seek to achieve closer links with our European neighbours' that a renewed bid to enter the EEC might be possible. In any case of course, manifesto pledges can mean little or nothing: certainly, once Labour was in power, nothing much was heard about improvements to Commonwealth trade and co-operation. The sub-section 'Prospects for Peace' was partly an historical review of the perceived Conservative failure to develop détente with the Soviet Union, and partly a promise to do something about this by developing East-West trade, pursuing disarmament and bringing Communist China into the United Nations. This was tied to stronger support for the UN, including the creation of an international police force, with the promise that Labour would 'end the supply of arms to South 
Africa', where apartheid held sway. But once again it was a case of promises being ambiguous, an attempt to placate the Left while the election took place. In power Labour restricted arms supplies to South Africa rather than ending them altogether, there was no breakthrough on détente and the government was severely criticised in the UN over its 'colonialist' policies towards Aden and Southern Africa. ${ }^{25}$

While foreign and defence policy was placed third in the trio of parts that made up the Labour manifesto, they held pride of place in the Conservative one. Fitting Douglas-Home's preferences, the manifesto led off boldly with a statement of the Conservatives' claim to be the party of patriotism and a strong defence, while also stressing the readiness of recent governments to talk to the Soviet bloc. 'Our policy of peace through strength has brought Britain safely through years of tension and danger', the section loftily began, 'It contributes to the security of the free world. It provides the realistic basis for better relations between East and West. It keeps this country in her rightful place at the centre of international affairs.' Labour, in contrast, was accused of being 'deeply divided' on foreign and defence issues, seeking a policy of 'nuclear abdication' that would 'relegate Britain to the sidelines.' The manifesto pointed to the one great success for the policy of East-West contacts, the nuclear Test Ban Treaty of the previous year, a breakthrough which rather blunted Labour's attempts to scare the public with the dangers of nuclear confrontation. It laid emphasis on hopes for further measures of nuclear arms control and even expressed a readiness to discard British weapons, but only in the context of multilateral talks. Mention was made of the agreement to place Britain's nuclear weapons at the disposal of NATO; but, significantly, the words 
'Multilateral Force' were avoided and it was categorically stated that the assignment of such forces to the Alliance would be 'subject to our right to deploy them at discretion.' The other main 'external' subject covered was the Commonwealth, where it was a case of neutralising Labour's claim to be the party that could best defend ties. The Conservative manifesto highlighted the success of a recent Commonwealth conference, the number of countries (thirteen) that had achieved independence since 1951, recently-announced plans to create a permanent Commonwealth Secretariat and the scale of British aid to Commonwealth countries. Other questions, which received merely a brief mention, were support for the United Nations, the need for an 'Atlantic partnership' and a readiness to work with other Western European countries, while acknowledging that entry 'into the European Economic Community is not open to us in existing circumstances.' Surprisingly, international trade was barely mentioned. ${ }^{26}$

A desire by both main parties to avoid embarrassment on international questions clearly emerges from the manifestos. Each tried to criticise the other in general terms the Conservatives were condemned as unimaginative, Labour for being divided - and on key issues where there could be said to be a popular consensus, like the need for a strong defence, East-West détente and fostering of the Commonwealth, both main parties simply claimed that they could do the job better than the other. On more controversial issues there was always the possibility of vagueness (as with Labour on the future of nuclear weapons) or ignoring a question (as with the Conservative refusal to mention the MLF by name). 


\section{The Campaign}

The 1964 campaign, beginning on 15 September, was an unusually long one. National Opinion Polls, the agency which had come closest to predicting the 1959 result, believed the Conservatives were ahead but only by the narrowest margin and Conservative Central Office warned candidates that, 'Experience of post-war elections has shown that... Labour... are normally late starters and strong finishers. ${ }^{27}$ So it proved. Despite a poor start to Wilson's campaign, which only really opened with his first press conference on 25 September, opinion polls began to move back in Labour's favour in the newspapers of Sunday, 4 October. This shift was evidently linked to evidence that Britain's international economic position was much weaker than the Conservatives had tried to portray. Trade figures released on 30 September, showed a deficit of $£ 73$ million forcing the government to announce an increase in borrowing from the International Monetary Fund (IMF). On 1 October the Daily Telegraph sensed the shift in Labour's approach, from pressing its reform programme to attacking the Conservatives' economic record and Tony Benn, who had been worried about the state of the Labour campaign, noted 'The trade crisis has given us our opening and the chance to alert a partly apathetic public to the consequences of Tory rule if they are returned.' In his memoirs Douglas-Home insisted that the deficit was small and blamed Wilson for the ensuing uncertainty on the money markets. In fact both parties were responsible for the crisis that now threatened the Pound. Conservative attempts to embarrass Labour, by asking whether the party would devalue the Pound, backfired by seeming to prove that a serious monetary crisis was about to occur. While 
on 2 October George Brown, Labour's deputy leader, told television viewers, 'This country is lurching towards the biggest economic crisis since the war. ${ }^{28}$ Such exaggerated rhetoric helped to put the Conservatives on the defensive, but it also ensured that the financial markets remained jittery as Labour took office, setting the new government on an uneasy road towards spending restraint and eventual devaluation, as well as the liquidation of Britain's world role. 'They have staked everything on a desperate bid to talk the nation into financial crisis', said Douglas-Home in Glasgow on 5 October, accusing Labour of a 'harem scarem' campaign ('running hares and starting scares'). But by then the damage was done and the Prime Minister's gruelling schedule of public meetings was exhausting him, making it difficult to rally the Tory campaign. ${ }^{29}$

While Wilson rarely gave full treatment to foreign and defence issues, being aware of the danger to Labour unity if he became too specific, Douglas-Home regularly referred to nuclear weapons. ${ }^{30}$ At the outset, he decided the retention of the nuclear deterrent would be one of the three main planks on which he would fight the election, the others being how to reconcile full employment with low inflation and the argument that 'Socialism always made things worse. ${ }^{31}$ Labour briefs could be caustic about this unimaginative approach: 'Sir Alec's standard speech is concocted from a limited number of basic ingredients whose recipe is hardly altered whatever the occasion. ${ }^{32}$ Yet, for a time his tactics seemed to pay off. Tony Benn, for one, recognised that in the early phase of the campaign - when no single issue came to the fore - Wilson's interventions lacked a consistent message 'whereas Douglas-Home is out in the streets plugging the two themes of prosperity and the need for the Polaris submarine. 33 
The older man might be a poor television performer and had set himself a more demanding schedule, but until early October he seemed to have the edge. On 5 October, in what was seen as his best speech of the campaign, delivered in Glasgow, he criticised Labour's 'council of weakness and despair' on defence, with its apparent readiness to surrender nuclear arms when France and, more worryingly for the West, Communist China were just obtaining them. France had carried out its first atomic explosion in 1960; China was rumoured to be on the verge of following. In his closing speech of the campaign Douglas-Home took up the same theme, declaring 'the world is still a dangerous place. It is just at this moment, when France and China are becoming nuclear powers, that the Socialists would propose to discard all control by a British government over Britain's nuclear arm...' which was 'our sole defence against blackmail or attack by a nuclear power and it is our only passport to the highest councils of the world...' Wilson only fully focused on nuclear issues in one speech, though it was taken up by other speakers, notably the former Prime Minister, Lord Attlee, who cuttingly remarked in a broadcast at the end of the campaign that 'if a man had any personality he could put across British policy without a nuclear bomb in his hand. ${ }^{34}$

Few other defence issues seemed to matter. Aviation minister Julian Amery did try to sway voters, especially in his own seat of Preston North, with talk of Labour cancelling the supersonic fighter-bomber, TSR-2, on which many jobs in the British aerospace industry depended. But Wilson denied the rumours about cancellation, stating, in his usual evasive style that if the aircraft "works and does what is expected of it at 
reasonable cost we shall want it...' (This was typical Wilson evasiveness. Actually the aircraft did not survive Labour's first year in office. $)^{35}$ As to foreign policy questions, even questions that involved, or threatened to involve, British armed forces - such as Aden, the Malaysia-Indonesian 'confrontation' and Vietnam - failed to arouse much interest. This was probably because of the combination of a lack of crisis on any of these issues and a consensus over how Britain should deal with them. In Aden the situation seemed to be quite settled an upsurge in violence occurred only in the months following the election. While the 'confrontation' with Indonesia was at a difficult phase, both main political parties supported a firm line on deploying British troops in Borneo to deal with it. As to Vietnam, it had seemed to be heading for crisis in early August, when there was US-North Vietnamese naval clash in the Gulf of Tonkin, but this incident had simply been followed by limited American air strikes and the US was now focusing on its own national election campaign, in which President Johnson tried to portray himself as the ‘peace candidate' against his Republican opponent, Barry Goldwater. In any case, while neither main British party showed any desire to become directly involved the conflict in Southeast Asia, there was general sympathy at this point for US policy in Vietnam. The escalation of US military involvement would only come in early 1965.

Looking away from specific issues to the more general debate, over whether Britain should look to a European future and abandon its world role, here too the prevailing consensus militated against a real debate. As seen above, in his pre-election statements Wilson had suggested support for the British presence in Aden and Malaysia, and recent research into the withdrawal from bases 'East of Suez' shows that the Labour 
leadership only decided on withdrawal thanks to a gradual re-evaluation of policy after the election was won. ${ }^{36}$ The EEC, which became a more pressing issue a few years later, never took off as an issue although Labour periodically reminded voters of the failed entry bid. Once again this was probably because there was general acceptance at this point that, even if the Conservatives had pressed the case for entry, there seemed little likelihood that de Gaulle would let the British in. True, the EEC was sometimes linked, in statements, to the future of the Commonwealth: Wilson claimed at one point that Conservatives wished to 'sell the Commonwealth down the river' for the sake of getting into the EEC, while Heath claimed Labour wanted to turn the Commonwealth into a closed bloc. But since both manifestos stated that Commonwealth links would be defended, it is not surprising if voters saw little difference between them. Nor did opinion polls suggest the electorate cared much about the Commonwealth or the developing world - which makes it difficult to explain why Wilson regularly mentioned Labour's intention to expand the foreign aid programme. Most likely this was designed to please the Left within his party. But also, rather like Douglas-Home's conviction that nuclear weapons must be retained, a desire to help the developing world represented a personal belief of the Labour leader. ${ }^{37}$

Residual Imperial questions did have an impact in the form of immigration, after an influx from the West Indies and from Asian communities in East Africa. They numbered about 800,000 by the time of the election. The Conservative front bench did not exploit the issue much, though Douglas-Home did defend the 1962 Commonwealth Immigrants' Act in a speech in Bradford on 6 October, arguing that this had prevented an 
inundation of immigrants. ${ }^{38}$ For the Conservatives it was an issue fraught with difficulties, not least because some candidates did try to exploit immigration on racist grounds, most famously in the Birmingham constituency of Smethwick, where Peter Griffiths was trying to defeat Labour's Shadow Foreign Secretary, Patrick Gordon Walker. On 24 September the Birmingham Post summed up the Conservative campaign there with the headline 'Labour win will mean race riots', forcing Douglas-Home to condemn such statements. ${ }^{39} \mathrm{He}$ also made clear, in an open letter, that once immigrants had arrived they must be treated as equals ${ }^{40}$ and it is significant that the Conservatives were trying to woo the immigrant vote in some constituencies, with Central Office arranging for the translation of election material into Hindi and Urdu. ${ }^{41}$ But if the Conservatives were embarrassed by accusations of racism, Labour was concerned that outright opposition to the 1962 Act would prove unpopular on and there was pressure on Wilson from Transport House to make clear that Labour policy - based on introducing quotas in consultation with the Commonwealth - would hold immigration figures down. ${ }^{42}$ Actually, there were only about four constituencies where immigrants were numerous to enough to create real concerns about unemployment. The leaderships of both main parties generally avoided the issue and, by election time, they could both be said to agree on the need for controlled immigration. But in Birmingham in particular some constituency Conservative organisations continued to exploit the issue and Smethwick proved controversial because Gordon Walker was such a high profile figure, who lost his seat against the national trend. He had been a vocal opponent of the 1962 Act and his opponent, Griffiths, was determined to link immigration to crime, disease and unemployment in a shamelessly populist campaign with which his donnish opponent 
could not compete. The only other constituency where Labour lost a long-held seat apparently because of immigration was Eton and Slough, where Fenner Brockway had been MP since 1951. But here the Conservative candidate did not overtly try to exploit the question. ${ }^{43}$ The problem was hardly decisive, then. But, given the narrowness of Labour's majority, even the loss of two seats could be considered important.

Neither of the main foreign policy spokesmen featured much in the campaign, a factor that may have reinforced the feeling that international issues were unimportant. For Gordon Walker, understandably, the priority was to try to retain his Smethwick seat. As to 'Rab' Butler, he seemed to be losing his interest in politics, becoming a lacklustre Foreign Secretary, living under the shadow of the Prime Minister, who was not only more knowledgeable about international affairs but had also beaten him in the fight for the leadership after Macmillan's resignation. Thanks it seems to his own indifference, Butler did not have much of a role in preparations for the campaign and Douglas-Home decided that, if the Conservatives were re-elected, Butler would be replaced at the Foreign Office. Small wonder that Butler appeared at only one party press conference and in only one television election broadcast. His only memorable contribution to the campaign was a gaffe on 8 October when he told a Daily Express reporter that opinion could run away from the Conservatives in the closing days. ${ }^{44}$

It is significant that there were two international events which, had they happened just a few days earlier, could have caused doubts in voters' minds about a change of government at this point. In writing to Douglas-Home to commiserate after the election 
defeat, David Ormsby-Gore, the Ambassador to Washington, wrote that 'Almost anything could have tipped the balance. Khrushchev's removal from office twelve hours earlier, China's nuclear explosion thirty-six hours earlier or just Rab keeping his mouth shut for once.' Instead news of the long-predicted explosion of an atomic bomb by Communist China came only the day after the election while news of the overthrow of the Soviet leader in a Kremlin coup came only a few hours before the polling booths shut, too late for the evening newspapers and any television broadcasts that might have mattered. Even Wilson later acknowledged, 'It was an open question whether, if the news from Moscow had come an hour or two before the polls closed, there would have been an electoral rush to play safe and to vote the existing Government back into power.' It was a theme taken up by Douglas-Home: 'if the Chinese had happened to give out the news of the explosion of the bomb day or two earlier' might the day have been saved. Yet he was also experienced enough to recognise that ruminating over such 'ifs' was a pointless exercise. ${ }^{45}$ By 3 p.m. on Friday 16 October it was clear that Labour had won the election even if, once all the votes were counted, the overall majority was a bare four seats.

\section{PART 2: ANALYSIS.}

\section{The Nuclear Issue}

Having reviewed the main events of the 1964 campaign from the perspective of international questions, what of the questions posed at the outset? Of particular 
importance, given its centrality to the losing Conservative campaign, why did DouglasHome focus so narrowly on the nuclear issue and how wise was this strategy? It is not enough to argue that it was unwise because it did not forestall defeat. Many issues may have influenced the outcome of the election campaign, one of the longest and closest in the twentieth century. Although Labour headquarters at Transport House noted that, by 11 October, 'almost everybody expects Labour to win', right down to the end seasoned observers refused to guess the likely outcome. The US embassy for example, refused to do so even in the face of pressure from Washington for a prediction; while in Downing Street, a memorandum was prepared on what to do in the event of electoral 'deadlock. 46 Given the view that Labour may have won simply because of the feeling that it was 'time for change', the interesting question is how Douglas-Home came so close to victory, and this after his party had already won three elections in succession. After all, only a few hundred votes in a handful of key constituencies could have given the Conservatives a fourth victory.

After the demoralising demise of the Macmillan premiership in 1963, DouglasHome was in many ways the Conservatives greatest asset and, since no single issue of policy came to dominate the campaign, perhaps his consistency in pushing the need for a British deterrent was not too damaging. It is significant that, having won the election narrowly and being only too aware that another would be necessary before long, Wilson gave up talk of abandoning the Polaris. He probably intended to do this all along, being well aware that the deterrent 'had an emotional appeal to the man in the pub. ${ }^{, 47}$ DouglasHome's persistence in criticising Labour on nuclear defence was certainly understandable 
in one sense: a Gallup poll showed that more voters (37\% to $21 \%)$ preferred to retain the nuclear deterrent than scrap it whereas - and this is the key point - on almost all other major issues Labour was ahead of the Conservatives ${ }^{48}$ As noted above, given the virtual civil war in Labour ranks over unilateral disarmament under Gaitskell, the Prime Minister may have hoped that, by pressing the issue, he could rekindle the embers and so ruin Wilson's carefully crafted policy of restoring party unity. Furthermore, bolstered by his own inner certainty that nuclear weapons were vital to British influence and security, this was 'by common consent... the subject on which he spoke most effectively.' These were all understandable reasons for playing the nuclear card.

Nonetheless, the case that Douglas-Home's was an unwise strategy seems easier to sustain. For the nuclear issue never proved to be a trump card, because Labour never actually undertook to scrap nuclear weapons (even if they often gave the impression that they would abandon Polaris) and, thanks to Wilson's low-key approach to defence no serious arguments broke out within the Labour camp. In any case voters did not feel as strongly on this question as they did on domestic ones. The Conservatives were ahead in polls over Summer, Wilson needed the largest swing of votes since 1945 in order to win and Labour's campaign got off to an uncertain start, so there is a strong case for arguing that the outcome of the election was far from inevitable; that it was, in fact, the Prime Minister's to lose. A Labour post-mortem on the result showed that even the winning party felt it less of a victory for Wilson (in fact the number of Labour voters was slightly down on the 1959 total) than a loss for Douglas-Home (with many Conservatives staying at home or voting Liberal) ${ }^{49}$ It is significant that other Conservative frontbenchers had 
less to say on nuclear weapons, some of them evidently fearing that the whole debate merely risked worrying people. The only exception was Peter Thorneycroft who, as Defence Secretary could hardly avoid the issue, and he only made much of nuclear weapons at the party's daily press conference on 7 October. ${ }^{50}$ Towards polling day the feedback from candidates to Conservative Central Office was that 'Defence and independent nuclear disarmament are now established. We should now concentrate on home policy...' Although Conservative morale remained high until the end, it was feared that Labour talk of 'Time for a Change' and 'Wasted Tory Years' were proving effective. ${ }^{51}$ Yet the party leader continued to plug the nuclear message until the end. Even Douglas-Home's official biographer judged that the Prime Minister played on the nuclear issue against 'all advice' and 'ran a Foreign Secretary's campaign rather than a Prime Ministerial one. ${ }^{52}$

Butler's gaffe, at a key moment, in expressing the fear that the election was lost; the rowdy nature of certain Conservative election rallies thanks to the behaviour of hecklers; and, of course, the announcement of the IMF loan - all of these worked against the government in early October. But the Prime Minister might also have relaxed his pressure on the nuclear front at that point and focused on other, more significant issues for electors, especially after Wilson had proven that he was too astute a politician to say much about nuclear weapons himself. Douglas-Home may have felt more confident dealing with international matters, but playing to his strengths was not necessarily wise given that the voters wanted to hear most about schools, employment and living standards. Even if one accepts that his strategy had some justification, especially because 
nuclear defence was the only real issue where he had the edge over Labour, his almost obsessive focus on one topic throughout the campaign was hardly wise. In this, albeit negative sense, international issues may have helped ensure that the incumbent premier could not stem the Labour tide and had a profound effect on the election. In his memoirs, written in the mid-1970s, he was still angry at Wilson's tactics over Polaris, arguing that 'he was, to put it bluntly, ignorant or irresponsible.' But Douglas-Home's condescending assertion that his opponent had been 'careless of the first duty of a government which is to provide security for its country' showed a rather quaint, gentlemanly view of politics at election time, when Labour was desperate to return to power after thirteen years of Opposition. And the argument that Wilson had 'frightened' voters, many of whom were 'anxious about nuclear contamination of the environment', does not carry much weight given that Wilson had barely mentioned nuclear matters during the campaign and that the

Test Ban Treaty had already helped assuage popular concerns about the environment. ${ }^{53}$

\section{Britain's place in the world}

What then of other international issues in the campaign? Why did they feature so little and why in particular was there no debate about Britain's role in the world, especially given that the future of the 'three circles' was being called into question? In part this seems to have been because of the opinion polls that suggested voters themselves were far more interested in domestic problems and, unlike some political analysts at the time, did not link these problems to the burdens created by defence spending and the world role. As a result neither party machine put a major effort into educating their candidates 
about foreign policy and defence, beyond giving a basic idea of the more obvious issues: a series of ninety-seven 'Questions of Policy' papers sent out to constituencies by Central Office during the campaign included only about half-a-dozen on foreign policy and defence ${ }^{54}$; while a similar series of 'Questions and Challenges to Labour Candidates' usually had foreign affairs and defence as a relatively short section near the end. ${ }^{55}$ Central Office also recognised that, while women were more likely to vote Conservative than men, the former were more concerned with domestic issues. ${ }^{56}$ All of which makes Douglas-Home's expertise in foreign and defence policy look even more of a liability for his party. But to the general public indifference needs to be added the fact that, aside from the balance of payments statistics, no other international issue sprang up to surprise the parties and electorate during the campaign. The EEC issue was currently quiescent, as were Vietnam, Aden and Cyprus, while the fall of Khrushchev and China's first atomic test came too late to justify Douglas-Home's preoccupation with nuclear security.

It is also evident, however, that the two main parties engineered a position where, rather than heeding Dean Acheson's concern and debating Britain's post-imperial role in the world, they sought to portray themselves as defenders of a consensus position. This was especially clear in their manifestos, where the message was that both would ensure a strong defence, preserve the Commonwealth, maintain the Western alliance and develop détente with the East. There was also a consensus around the need to face up to Indonesia in the 'confrontation', achieve a positive balance of payments and control immigration while avoiding racial discrimination. Why parties should emphasise the consensus in their manifestos, rather than challenge it, is obvious. In general this is the best way to 
keep voters' sympathy and ensure the election is won. It also makes it more difficult for the opposition to open up a line of attack against you. This feature of campaigns arguably justifies the tendency of international historians to pay little attention to elections. Election campaigns should ideally, perhaps, be the occasions for a full debate on any number of issues, but they rarely are. It is not that parties avoid all hint of differences between them: in 1964 both manifestos tried to castigate the other party for weakness of division. The overall message, however, was that the consensus was best preserved by one party rather than the other. The value of elections for understanding the evolution of foreign and defence policy is rendered even more dubious by the tendency of parties to make vague, evasive statements designed to avoid controversy and criticism. Thus a cursory reading the Labour manifesto and Wilson's speeches during the 1964 campaign might suggest that his incoming administration would abandon Polaris, focus its energies on building up the Commonwealth, expand overseas aid, end arms sales to South Africa and preserve the TSR-2. In practice, however, none of these was the case.

In one sense, looking at 1964, international questions seem little different to domestic ones in their impact. There is often a tendency for parties, on domestic policies too, to appeal to the consensus and create images of difference with their opponents, while being ambiguous about where concrete differences actually lie. As elections approach, many decisions are postponed, while third parties sit back awaiting the outcome. Vagueness and evasion are common in manifestos. Special factors, like immigration and the fate of TSR-2, will always exist in particular constituencies. It could be argued that international issues are different to domestic ones in the sense that world 
events are more difficult for British politicians to predict and control. But, again, the two crises that could have blown up during the campaign, the Chinese atomic bomb and the fall of Khrushchev, failed to arrive early enough to save Douglas-Home. He had had rather better luck in the months ahead of the campaign, especially with the Spanish frigates episode. But luck, of course, has a tendency to run out when it is most needed.

This is not to say that immigration, TSR-2 and Britain's standing in the world were unimportant in such a close run contest. Fears about how Labour would handle these issues may have helped pare Wilson's majority to a minimum. The balance of payments deficit and Douglas-Home's determination to play on the nuclear issue certainly deserve to be considered significant. Whether they had as much effect on voters as standards of living or the simple feeling that it was 'time for a change' after thirteen years of Conservative government is debateable in light of the opinion polls evidence. But, it is significant that two major swings in opinion during 1964 - to the Conservatives in August after the Spanish frigates episode; to Labour after the September trade figures can be linked directly to international concerns. Furthermore, the international context helped fuel the notion that it was 'time for change', because in Douglas-Home's election strategy could be seen the fruits of thirteen years of rule in which Conservative leaders spent far more time on international questions than they did on domestic ones, preoccupied with Britain's world role and the maintenance of strong armed forces. As the Empire evaporated, numerous countries outstripped Britain in terms of economic growth and the country failed to enter the EEC, the sense of national malaise deepened. That malaise had its domestic origins too, but it was made all the starker in the early 1960s by 
comparisons to EEC growth rates, the burgeoning nuclear might of the Soviet Union and the vigorous leadership of John Kennedy across the Atlantic. It is in this intangible sense that international considerations may have had their most important impact on the 1964 election. Only time would show if Labour could alter the country's sense of decline.

\section{Conclusion}

It can be argued that, throughout the twentieth century the main parties ensured that foreign and defence policy did not loom large in most elections through a deliberate tactic of avoiding controversial positions on questions of national security. Whatever the outcry from its radical wing, the Liberal government was careful to maintain the French entente and the strength of the Royal Navy in the decade before the First World War; and whatever its position as the defender of the Empire, the Conservative party was careful to promise a pacific policy between the wars. There generally emerged a broad consensus about foreign and defence policy in both these periods, just as there emerged a broad consensus behind an anti-Soviet, pro-NATO policy after 1945, linked to the maintenance of a global politico-economic role and a close alliance with the United States. In 1964 the consensus on foreign policy meant that both main parties promised to support the Commonwealth, improve exports, back the UN and seek East-West détente, the implication being that Britain's world role would be maintained, even if Labour seemed to hint that the nuclear role would be abandoned. In the next election, in March 1966, with Polaris retained and a promise of limited defence cuts, the consensus still held good and Labour won handsomely. 
Yet the twentieth century experience also showed that failure in foreign and defence policy could prove costly for governments, even when they had originally sought only to mirror the consensus. The drawn-out nature of the Boer War helped ensure the Conservatives' decline after 1900, just as the lacklustre performance of Asquith's Liberals cost them popular respect after 1914. Appeasement cost Chamberlain dear, while involvement in the Korean War, linked to substantial defence expenditure, helped divide Attlee's Labour government in 1950-51. Similarly, in the 1960s, it was the decision to maintain a global presence as much as anything else that made it difficult to address the country's economic difficulties. Once in power under Wilson, Labour failed to cut back quickly enough on defence expenditure, hopes of Commonwealth cooperation came to nothing and, by 1967 , Wilson was thrown back on another attempt to enter the EEC. The failure of that attempt, alongside the devaluation of Sterling in November and an accelerated withdrawal from 'East of Suez' announced soon afterwards, proved a turning point for the country's international role. In the following years the Pound was stabilised on the foreign exchanges, withdrawal from the Middle and Far East proceeded smoothly and the government persisted in its efforts to enter the EEC, so that entry talks finally became possible in 1970. But the sense of being controlled by events rather than controlling them cost Labour dear and set them on the road to defeat in June that year. In retrospect, while a cautious, consensus-based policy may have seemed the best course for the parties fighting in 1964, a more radical look at the world role might have served the country, and the incoming Wilson government, better. 


\section{Notes}

${ }^{1}$ I am grateful to the British Academy for helping fund the archival visits for this article and to the two anonymous readers who commented on an earlier draft.

${ }^{2}$ The historian is Pimlott, Ben. Harold Wilson. London: Harper Collins, 1992): 311-18. Among works on British elections see for example: Rose, Richard. Influencing Voters. London: Faber, 1967; Heath, Anthony et al. How Britain Votes. Manchester: University Press (which does look on pages117-21 at nuclear weapons in the 1983 election); Denver, David. Elections and Voting Behaviour in Britain. London: Philip Allan, 1989.

${ }^{3}$ Bartlett, C. J. 'The Special Relationship'. London: Longman, 1992: chapter 5; Dobson, Alan, Anglo-American Relations in the Twentieth Century. London: Routledge, 1995: 131-9; and Ovendale, Ritchie. Anglo-American Relations in the Twentieth Century. Basingstoke: Macmillan, 1998: chapter 8.

${ }^{4}$ On the British and the Vietnam War see especially Busch, Peter. All the Way with JFK? Oxford: University Press, 2003; Ellis, Sylvia, Britain, America and the Vietnam War. New York: Praeger, 2004. But the 'confrontation' between Malaysia and Indonesia was just as important to Britain in 1964: see especially Jones, Matthew. Conflict and Confrontation in South-east Asia. Cambridge: University Press, 2002.

${ }^{5}$ On the East of Suez decision see Dockrill, Saki. Britain's Retreat from East of Suez. Basingstoke: Macmillan, 2002; and Pickering, Jeffrey, Britain's Withdrawal from East of Suez. Basingstoke: Macmillan, 1998. On Britain's international economic position and the problems of Sterling see Tomlinson, Jim, The Labour Governments 1964-70, Volume 3, Economic Policy. Manchester: University Press, 2004. 
${ }^{6}$ On Aden see especially Pieragostini, Karl. Britain, Aden and South Arabia.

Basingstoke: Macmillan, 1991. And on Rhodesia, Windrich, Elaine. Britain and the Politics of Rhodesian Independence. Lodon: Croom Helm, 1978.

${ }^{7}$ The importance of the 1960s for seeing a breakdown of the 'three circles' has long been recognised. See Sanders, David. Losing an Empire, Finding a Role. Basingstoke: Macmillan, 1990: 112-20 and 204-10; and Reynolds, David. Britannia Overruled. London: Longman, 1991: 226-33.

${ }^{8}$ Dockrill. Britain's Retrea: chapters 1-2.

${ }^{9}$ For archive-based reviews of Conservative policy in the years before 1964 see Kaiser, Wolfram and Gillian Staerck, eds. British Foreign Policy, 1955-64. Basingstoke, Macmillan, 2000; and Ashton, Nigel. Kennedy, Macmillan and the Cold War. Basingstoke: Palgrave, 2002.

${ }^{10}$ House of Commons Debates, $5^{\text {th }}$ Series, Volume 690: column 480.

${ }^{11}$ Butler, D. E. and Anthony King. The British General Election of 1964. London: Macmillan, 1965: 26-27 and 93-4. On Wilson's overseas visits: Ziegler, Philip. Wilson: the authorised life London: Weidenfeld and Nicolson, 1993: 147-50. On Spanish frigates: Thorpe, D. R. Alec Douglas-Home London: Sinclair-Stevenson, 1996: 374; and Public Record Office (PRO), Kew, CAB 128/38, CM(64)31 $1^{\text {st }}$ (11 June).

${ }^{12}$ Roth, Andrew. Harold Wilson. London: Macdonald, 1977: 297-8 and 300; Wilson, Harold. The Relevance of British Socialism. London: Weidenfeld and Nicolson, 1964: chapters 5-7. Britain's place in the world economy was also central to Wilson's speech to the TUC on 7 September: Trades Union Conference Report, Blackpool, 1964: 381-6. 
${ }^{13}$ For example, when Wilson spoke at West Woolwich: Conservative Party Archive (CPA), Bodleian Library, Oxford, CCO/4/9/187, note on public meetings (29 September).

${ }^{14}$ Butler and King. 1964: 128-9.

${ }^{15}$ Butler and King. 1964: 26, footnote, and 149.

${ }^{16}$ Diary, 23 September 1964, Benn, Tony. Out of the Wilderness: diaries, 1963-67.

London: Hutchinson, 1987: 146; Pimlott. Wilson: 309-10.

${ }^{17}$ Foreign Relations of the United States, 1964-68, Volume XIII. Washington: US

Government Printing Office, 1999: 41-3.

${ }^{18}$ Lord Butler, The Art of the Possible. London: Hamish Hamilton, 1971: 253 and 258-9.

${ }^{19}$ Hughes, Emrys. Alec Douglas-Home. London: Housman's, 1964: 96-98.

${ }^{20}$ Embassy Report, 14 September 1964, quoted in Ziegler. Wilson: 157-58.

${ }^{21}$ Morgan, Austen. Harold Wilson. London: Pluto, 1992: 254.

${ }^{22}$ Bodleian Library, Oxford, MS. Wilson c. 1367, handwritten draft (undated); Roth. Wilson: 301; Ziegler. Wilson: 157.

${ }^{23}$ CPA, CCO/4/9/196, 'Questions of Policy' No.30 (23 September).

${ }^{24}$ MS. Wilson c. 1370, 'Labour Defence Policy’ (22 September). See also Talking Points: Defence Policy. London: Labour Party, 1964.

${ }^{25}$ Craig, FWS, ed. British General Election Manifestos, 1918-66. Chichester: Political Reference Publications, 1970: 241-46 and see 230 and 233-7. On Commonwealth see also Noel, G. E. Harold Wilson and the New Britain. London: Gollancz, 1964: 149-50. On policy in government see Young, John W. The Labour Governments 1964-70, volume 2, International Policy. Manchester: University Press, 2003. 
${ }^{26}$ Craig. Manifestos: 213-17.

${ }^{27}$ Labour History Archive (LHA), Manchester, '1964 General Election’ boxes (GE), 'Miscellaneous File', NOP poll, 17-20 September; CPA, Election Memorandum No.3 (22 September).

${ }^{28}$ Diary, 1 October, Benn. Wilderness: 148; Home, Lord. The Way the Wind Blows. London: Collins, 1976: 213; Butler and King. 1964: 116-18.

${ }^{29}$ Young, Kenneth. Alec Douglas-Home. London: Dent, 1970: 212; Times, 6 October. For leaders' itineraries: CPA, CCO/20/17/9; MS. Wilson c. 1368.

${ }^{30}$ Wilson's main speech on foreign-defence policy was at Wandsworth, 5 October, but he spoke on defence (mainly naval) at Plymouth on 27 September and was pressed hard on nuclear issues at his press conference of 10 October: The Times, 28 September, 6 October; Daily Telegraph, 11 October.

${ }^{31}$ CPA, CCO/20/17/17, notes for manifesto launch (17 September); Home. Wind: 212.

${ }^{32}$ MS. Wilson c.1367, ‘Information Series No.2 (June 1964).

${ }^{33}$ Diary, 1 October, Benn. Wilderness: 148.

${ }^{34}$ The Times, 6 October; Butler and King. 1964: 119, 126 and 130-31.

${ }^{35}$ Roth. Wilson: 304.

${ }^{36}$ The fullest account is Dockrill. Britain's Retreat: chapters 3,4 and 6-9.

${ }^{37}$ Butler and King. 1964: 131-2.

${ }^{38}$ Ibid.: $119-20$.

${ }^{39}$ Thorpe, Douglas-Home: 369-70.

${ }^{40}$ CPA, CCO/500/24/196, Douglas-Home to Walker (27 September). 
${ }^{41}$ CPA, CCO/500/24/177, Central Office to Agents (9 September), Gower to Central Office (20 October).

${ }^{42}$ MS. Wilson c. 1370, Cunningham to Wilson (early October).

${ }^{43}$ See Sigham, A. W. 'Immigration.' In 1964, edited by Butler and King: 360-68. LaytonHenry, Zig. The Politics of Race in Britain. London: Allen and Unwin, 1984: chapters 15. On Smethwick: Pearce, Robert, ed. Patrick Gordon Walker: political diaries. London: Historians' Press, 1991: 41-44; Griffiths, Peter, A Question of Colour? London: Frewin, 1966: $152-79$.

${ }^{44}$ Howard, Anthony. RAB. London: Macmillan, 1987: 325-334.

${ }^{45}$ Ormsby-Gore to Douglas-Home, 16 October, in Thorpe. Douglas-Home: 369 and see 372-3; Wilson, Harold. The Labour Government. London: Weidenfeld and Nicolson, 1971: 2; Home. Wind, 215.

${ }^{46}$ LHA, GE, 'Secretary's Conference' file, 'Review of the Papers', 11 October; David Bruce Diary, 12 and 14 October, Virginia Historical Society, Richmond; PRO, PREM 11/4756, memorandum by Maitland, 16 October.

${ }^{47}$ Ziegler. Wilson: 208.

${ }^{48}$ Rose, Voters: 55-7.

${ }^{49}$ In twenty-one constituencies Labour were under one percent ahead of Conservatives: LHA, GE, 'General Secretary's Master File of Circulars', Final Election Report by the General Secretary (undated).

${ }^{50}$ Butler and King, 1964: 93 and 130.

${ }^{51}$ CPA, CCO/500/24/179, Intelligence Reports, Nos.19, 20 and 21 (13-15 October).

52 Thorpe. Douglas-Home: 372. 
${ }^{53}$ Home. Wind Blows: 213-14.

${ }^{54} \mathrm{CCO} / 4 / 9 / 196$, papers $12,14,19,30,40$ and 61 (18-29 September). This was roughly similar to the number prepared by Labour's Overseas Department for the campaign: LHA, 'General Election Circulars, 1964' file, which includes circulars on the UN, Commonwealth, nuclear deterrent, immigration, and the Congo, plus 'Labour's Policy for Peace' by Gordon Walker. GE 'Research Master' file also shows papers on Vietnam, Malaysia and MLF.

${ }^{55} \mathrm{CPA}, \mathrm{CCO} / 4 / 9 / 189$, Election Memoranda (with appended questions) Nos.3, 9 and 11 (22 September, 2 and 9 October).

${ }^{56} \mathrm{CPA}, \mathrm{CCO} / 20 / 17 / 9, \mathrm{CRD}$ memorandum (1 October). 